\title{
PEMBANGUNAN RUANG TERBUKA HIJAU DI PROVINSI KALIMANTAN BARAT
}

\author{
Oleh \\ Meta Indah Budhianti*)
}

\begin{abstract}
Abstrak
Penetapan besaran luas RTH ini bisa juga disebut sebagai bagian dari pengembangan RTH kota. Disayangkan, bahwa dalam hal pengelolaan RTH kota perlu konsistensi penerapan sesuai dengan RIK yang telah disepakati bersama agar RTHnya tetap bisa eksis, bahkan kualitas maupun kuantitasnya bisa terus meningkat. Perumusan permasalahan adalah Bagaimana pengaturan Pembangunan Ruang Terbuka Hijau di Provinsi Kalimantan Barat berdasarkan Peraturan Perundang-Undangan dan Bagaimana upaya pemerintah dalam pembangunan Ruang Terbuka Hijau di Provinsi Kalimantan Barat. Hasil penelitian ini adalah pengaturan pembangunan Ruang Terbuka Hijau di Provinsi Kalimantan Barat mengacu pada Undang-Undang Nomor 26 Tahun 2007 tentang Penataan Ruang dan Peraturan Menteri Pekerjaan Umum No. 05/PRT/M/2008 Tentang Pedoman Penyediaan dan Pemanfaatan Ruang Terbuka Hijau di Kawasan Perkotaan dan peran pemerintah memberdayakan lahan di setiap desa, kedepannya kita akan memberdayakan lahan di setiap desa dengan membangun ruang terbuka hijau. Minimal dalam satu desa itu ada lahan seluas 2 hektare untuk ruang terbuka hijau.
\end{abstract}

\section{Kata Kunci : Ruang Terbuka Hijau, Pemerintahan Daerah}

\section{A. PENDAHULUAN}

Berdasarkan Konferensi Tingkat Tinggi (KTT) Bumi di Rio de Janeiro, Brazil (1992) dan dipertegas lagi pada KTT Johannesburg, Afrika Selatan 10 tahun kemudian $(2002$, Rio + 10), telah disepakati bersama bahwa sebuah kota idealnya memiliki luas RTH minimal $30 \%$ dari total luas kota. Tentu saja 'angka' ini bukan merupakan patokan mati. Penetapan luas RTH kota harus berdasar pula pada studi eksistensi sumber daya alam dan manusia

\footnotetext{
*) Penulis adalah Dosen Fakultas Hukum Universitas Trisakti Jakarta
}

penghuninya, tidak hanya pada kuantitas luasannya saja. ${ }^{1}$

Penetapan besaran luas RTH ini bisa juga disebut sebagai bagian dari pengembangan RTH kota. Disayangkan, bahwa dalam hal pengelolaan RTH kota perlu konsistensi penerapan sesuai dengan RIK yang telah disepakati bersama agar RTHnya tetap bisa eksis, bahkan kualitas maupun kuantitasnya bisa terus meningkat.

Kota-kota di Indonesia nampaknya memiliki kesulitan untuk meningkatkan RTH salah satu contoh adalah Pemerintah Daerah DKI Jakarta, dapat

1 Hasni, Hukum Penataan Ruang dan Penatagunaan Tanah, (Jakarta: PT. Rajagrafindo Persada, 2010), h. 239. 
dilihat dari pengamatan sebagai berikut : jika target luas RTH dalam Rencana Induk Jakarta 1965-1986 adalah $37,2 \%$ (sangat ideal), maka dalam Rencana Umum Tata Ruang (RUTR) Jakarta 1985-2005, target tersebut turun menjadi 25,05\% (masih cukup ideal). Namun, dalam Rencana Tata Ruang Wilayah (RTRW) Jakarta 20002010, target luas RTH menyusut hanya sebesar 13,94\% (9.515 hektar, tidak ideal). Sementara luas RTH di lapangan, hanya berkisar 9,04\% (6.190 hektar, atau 'kritis') dari total luas kota Jakarta yang 66.152 hektar tersebut.Saat inin RTH Jakarta baru sebesar 9,84\% dari total luas wilayah.

Target yang semakin menyempit itupun, konon sulit direalisasikan, akibat terus adanya tekanan pertumbuhan dan kebutuhan sarana dan prasarana kota, seperti struktur fisik bangunan dan panjang jalur jalan yang semakin meningkat yang sejalan pula dengan peningkatan jumlah penduduk. Hal ini merupakan salah satu bukti kurang dihargainya eksistensi RTH yang sering di'korbankan' padahal sebenarnya bernilai ekologis dan ekonomis tinggi, bagi terwujudnya lingkungan kota yang sehat, secara fisik maupun psikologis.

Pada kenyataannya, formula rumusan penentuan luas RTH kota yang memenuhi syarat lingkungan kota yang 'berkelanjutan' ini, masih bersifat kuantitatif dan tergantung dari banyak faktor penentu, antara lain : geografis, iklim, jumlah dan kepadatan penduduk, luas kota, kebutuhan akan oksigen, rekreasi. Dapat disimpilkan, bahwa sehubungan dengan tuntutan waktu dan meningkatnya jumlah penduduk dengan segala aktivitas dan keperluan, seperti cukup tersedia 'ruang rekreasi' gratis, maka sebuah kota dimanapun dan bagaimanapun ukuran dan kondisinya, pasti semakin memerlukan
RTH yang memenuhi persyaratan terutama kualitas keseimbangan pendukung keberlangsungan fungsi kehidupan, adanya pengelolaan dan pengaturan sebaik mungkin, serta konsistensi penegakan hukumnya.

Kota yang berbatasan dengan pantai dapat dikembangkan menjadi daerah tujuan wisata yang sangat menarik bagi para investor sehingga investor tidak segan mengambil alih lahan dari warga untuk mendirikan pusat-pusat bisnis pariwisata. Disamping itu kota yang berbatasan dengan pantai dan laut perlu dilestarikan fungsinya agar dapat menunjang pembangunan secara berkelanjutan (Sustainable Development) untuk kesejahteraan manusia.

Perlu adanya pengertian dari seluruh warga penghuni kota, bahwa terdapat hubungan sangat strategis antara Pembangunan Kota dan RTRWK (yang didalamnya mengandung rencana RTH) merupakan rencana pembangunan kota-kota layak huni (Eco-cities). Rencana pembangunan kota yang layak huni tersebut harus terus disebarluaskan sehingga sebab/akibat dari perkembangan kota yang baik atau yang buruk dapat diketahui seluruh warga kota

Dengan semakin tipisnya RTH sebagai "paru-paru" kota di seluruh dunia secara akumulatif, tentu akan berakibat fatal, dicirikan dengan naiknya suhu bumi dan perubahan cuaca karena kenaikan suhu bumi tidak hanya dialami oleh satu pulau saja, tetapi akan terus merembet ke pulaupulau lain bahkan ke manca negara melampaui batas administratifnya masing-masing.

Berdasarkan uraian di atas, penulis merumuskan masalah sebagai berikut :

1. Bagaimana pengaturan Pembangunan Ruang Terbuka Hijau di Provinsi Kalimantan Barat berdasar- 
kan Peraturan Perundang-Undangan?

2. Bagaimana upaya pemerintah dalam pembangunan Ruang Terbuka Hijau di Provinsi Kalimantan Barat?

\section{B. PEMBAHASAN}

Ruang Terbuka Hijau di Provinsi Kalimantan Barat mengacu pada peraturan paling tinggi yaitu UU Penataan Ruang dimana Ruang terbuka hijau adalah area memanjang/jalur dan/atau mengelompok, yang penggunaannya lebih bersifat terbuka, tempat tumbuh tanaman, baik yang tumbuh secara alamiah maupun yang sengaja ditanam.

1. Pengaturan pembangunan Ruang Terbuka Hijau di Provinsi Kalimantan Barat mengacu pada UndangUndang Nomor 26 Tahun 2007 tentang Penataan Ruang dan Peraturan Menteri Pekerjaan Umum No. 05/PRT/M/2008 Tentang Pedoman Penyediaan dan Pemanfaatan Ruang Terbuka Hijau di Kawasan Perkotaan.

Penyusunan rencana tata ruang wilayah kota mengacu pada:

a. Rencana Tata Ruang Wilayah Nasional dan rencana tata ruang wilayah provinsi;

b. Pedoman dan petunjuk pelaksanaan bidang penataan ruang; dan

c. Rencana pembangunan jangka panjang daerah.

Penyusunan rencana tata ruang wilayah kota harus memperhatikan:

a. Perkembangan permasalahan provinsi dan hasil pengkajian implikasi penataan ruang kota;

b. Upaya pemerataan pembangunan dan pertumbuhan ekonomi kota;

c. Keselarasan aspirasi pembangunan kota; d. Daya dukung dan daya tampung lingkungan hidup;

e. Rencana pembangunan jangka panjang daerah;

f. Rencana tata ruang wilayah kota yang berbatasan; dan

g. Rencana tata ruang kawasan strategis kota.

Rencana tata ruang wilayah kota memuat:

a. Tujuan, kebijakan, dan strategi penataan ruang wilayah kota;

b. Rencana struktur ruang wilayah kota yang meliputi sistem perkotaan di wilayahnya yang terkait dengan kawasan perdesaan dan sistem jaringan prasarana wilayah kota ;

c. Rencana pola ruang wilayah kota yang meliputi kawasan lindung kota dan kawasan budi daya kota;

d. Penetapan kawasan strategis kota;

e. Arahan pemanfaatan ruang wilayah kota yang berisi indikasi program utama jangka menengah lima tahunan; dan

f. Ketentuan pengendalian pemanfaatan ruang wilayah kota yang berisi ketentuan umum peraturan zonasi, ketentuan perizinan, ketentuan insentif dan disinsentif, serta arahan sanksi.

Rencana tata ruang wilayah kota menjadi pedoman untuk:

a. Penyusunan rencana pembangunan jangka panjang daerah;

b. Penyusunan rencana pembangunan jangka menengah daerah;

c. Pemanfaatan ruang dan pengendalian pemanfaatan ruang di wilayah kota;

d. Mewujudkan keterpaduan, keterkaitan, dan keseimbangan antarsektor;

e. Penetapan lokasi dan fungsi ruang untuk investasi; dan 
f. Penataan ruang kawasan strategis kota.

Rencana tata ruang wilayah kota menjadi dasar untuk penerbitan perizinan lokasi pembangunan dan administrasi pertanahan. Jangka waktu rencana tata ruang wilayah kota adalah 20 (dua puluh) tahun. Rencana tata ruang wilayah kota sebagaimana dimaksud ditinjau kembali 1 (satu) kali dalam 5 (lima) tahun. Kota. Dalam kondisi lingkungan strategis tertentu yang berkaitan dengan bencana alam skala besar yang ditetapkan dengan peraturan perundang-undangan dan/atau perubahan batas teritorial negara, wilayah provinsi, dan/atau wilayah kabupaten yang ditetapkan dengan Undang-Undang, rencana tata ruang wilayah kota ditinjau kembali lebih dari 1 (satu) kali dalam 5 (lima) tahun. Rencana tata ruang wilayah kota ditetapkan dengan peraturan daerah kota.

Rencana rinci tata ruang sebagaimana dimaksud di atas ditetapkan dengan peraturan daerah kota.

Ketentuan perencanaan tata ruang wilayah kabupaten sebagaimana dimaksud di atas berlaku mutatis mutandis untuk perencanaan tata ruang wilayah kota, dengan ditambahkan:

a. Rencana penyediaan dan pemanfaatan ruang terbuka hijau;

b. Rencana penyediaan dan pemanfaatan ruang terbuka nonhijau; dan

c. Rencana penyediaan dan pemanfaatan prasarana dan sarana jaringan pejalan kaki, angkutan umum, kegiatan sektor informal, dan ruang evakuasi bencana, yang dibutuhkan untuk menjalankan fungsi wilayah kota sebagai pusat pelayanan sosial ekonomi dan pusat pertumbuhan wilayah.

Ruang terbuka hijau sebagaimana dimaksud di atas terdiri dari ruang terbuka hijau publik dan ruang terbuka hijau privat. Proporsi ruang terbuka hijau pada wilayah kota paling sedikit 30 (tiga puluh) persen dari luas wilayah kota. Proporsi ruang terbuka hijau publik pada wilayah kota paling sedikit 20 (dua puluh) persen dari luas wilayah kota.

Distribusi ruang terbuka hijau publik sebagaimana dimaksud di atas disesuaikan dengan sebaran penduduk dan hierarki pelayanan dengan memperhatikan rencana struktur dan pola ruang.

2. Upaya Pemerintah Dalam Pembangunan RTH di Provinsi Kalimantan Barat

Pesatnya perkembangan dan pembangunan daerah perkotaan menyebabkan semakin sempitnya lahan terbuka hijau. Oleh karena itu, pemerintah harus membuat peraturan beberapa persen dari bangunan harus ada lahan terbuka hijau,

"Setiap bangunan harus ada sekian persennya lahan terbuka hijau, sesuai dengan peraturan pemerintah" Namun karena sempit lahan yang biasanya dimiliki masyarakat, terutama di perkotaan besar, membuat orang berfikir kreatif untuk menyediakan lahan terbuka hijau tersebut.

Selain untuk memenuhi peraturan yang ada, lahan terbuka hijau juga dapat memberikan dampak yang sangat banyak, seperti mengurangi karbondioksida dan menambah oksigen.

Kepala Badan Lingkungan Hidup Kabupaten Kubu Raya, Nendar Soeheri.

Guna menangkal terjadinya global warming semakin parah, pemerintah akan membuat Ruang Terbuka Hijau (RTH) di setiap desa. Kebijakan itu sesuai dengan peraturan dan visi dan misi bupati dalam pemanfaatan 30 persen dari luas desa. 
Hal itu disampaikan langsung Kepala Badan Lingkungan Hidup Kabupaten Kubu Raya, Nendar Soeheri Perlu andil dari semua pihak, satu dintaranya peran pemerintah memberdayakan lahan di setiap desa, kedepannya kita akan memberdayakan lahan di setiap desa dengan membangun ruang terbuka hijau. Minimal dalam satu desa itu ada lahan seluas 2 hektare untuk ruang terbuka hijau. Dimana lahan ruang terbuka hijau itu nantinya akan di tanami sejumlah pohon yang bermanfaat. Terutama pohon lokal yang sesuai ciri khas dari setiap daerah. serta seluruh fasilitas hijau dalam ruang terbuka hijau. akan pasang semuanya disitu. Pohon-pohon yang buahnya bisa dimanfaatakan seperti langsat kalau di Desa Punggur. Muhammad Darmun menjelaskan dalam rangka koordinasi awal antara pemerintah pusat dengan pemerintah daerah untuk implementasi terkait pengendalian pemanfaatan ruang dan penguasaan tanah, tujuannya menjaga kesatuan antara lingkungan seperti sempadan sungai, RTH dan lainnya, untuk mewujudkan ruang Kota Pontianak yang aman, nyaman, produktif dan berkelanjutan.

Pemerintah daerah berupaya terus menjaga kelestarian lingkungan di antaranya menjaga area-area yang memang di dalam rencana tata ruang telah ditetapkan sebagai Ruang Terbuka Hijau (RTH) dan ruang-ruang milik publik, agar ekspektasinya dapat menjadi kemajuan kota untuk kesejahteraan masyarakat. Sebagaimana diketahui, dalam Undang-undang Nomor 26 Tahun 2007 tentang penataan ruang, disebutkan bahwa RTH pada wilayah perkotaan minimal sebesar 30 persen dari luas wilayah kota.

RTH memiliki banyak fungsi, diantaranya untuk memberi jaminan sistem sirkulasi udara dan paru-paru kota, mengatur sistem mikro agar sistem sirkulasi udara dan air secara alami dapat berlangsung lancar, sebagai peneduh, produsen oksigen dan penyerap air hujan serta penyedia habitat satwa dan penyerap poluten media udara.

Guna mengantisipasi terjadinya global warming semakin parah, Pemerintah Kabupaten Kubu Raya akan membuat Ruang Terbuka Hijau (RTH) di setiap desa. Kebijakan itu sesuai dengan peraturan dan visi dan misi bupati dalam pemanfaatan 30 persen dari luas desa.

Ruang Terbuka Hijau di seluruh Desa di Kubu Raya agar kedepannya bisa mengantisipasi terjadinya global warming yang semakin parah, langkah ini perlu andil dari semua pihak, satu dintaranya peran pemerintah memberdayakan lahan di setiap desa.

Pentingnya Pembenahan Ruang Terbuka Hijau (RTH)

Proporsi Ruang Terbuka Hijau (RTH) pada wilayah perkotaan minimal sebesar 30 persen yang terdiri dari 20 persen ruang terbuka hijau publik dan 10 persen dari ruang terbuka hijau privat. Proporsi 30 persen ini merupakan ukuran minimal untuk menjamin keseimbangan ekosistem kota, baik keseimbangan sistem hidrologi dan keseimbangan mikroklimat maupun sistem ekologis lain yang dapat meningkatkan ketersediaan udara bersih yang diperlukan masyarakat sekaligus dapat meningkatkan nilai estetika kota.

Asisten I Bidang Pemerintahan dan Hukum Setda Kabupaten Kubu Raya, Nendar Suhaeri mengatakan, target luas sebesar 30 persen dari luas wilayah kota dapat dicapai secara bertahap melalui pengalokasian lahan perkotaan secara tipikal. 
Nendar mencontohkan, RTH Taman Rukun Tetangga yang ditujukan untuk melayani penduduk dalam lingkup Satu RT, khususnya untuk melayani kegiatan sosial di lingkungan RT yang bersangkutan. Luas taman ini minimal $1 \mathrm{~m}^{2}$ Persegi per penduduk RT dengan luas minimal $250 \mathrm{~m}^{2}$ dan lokasi taman berada pada radius kurang dari 300 meter dari rumah-rumah penduduk yang dilayani. luas area yang ditanami tanaman ruang hijau minimal seluas 70 persen atau 80 persen dari luas taman, diamana pada taman ini selain ditanami berbagai tanaman, juga terdapat minimal Tiga pohon pelindung dari jenis pohon kecil atau sedang. Oleh karenanya apabila luas RTH publik maupun privat di kota yang bersangkutan telah memiliki total luas lebih besar dari peraturan atau perundangan yang berlaku, maka proporsi tersebut harus tetap dipertahankan keberadaannya.

Hal ini penting ditekankan, karena Ruang Terbuka Hujau (RTH) memiliki banyak fungsi, diantaranya untuk memberi jaminan sistem sirkulasi udara dan paru-paru kota, mengatur sistem mikro agar sistem sirkulasi udara dan air secara alami dapat berlangsung lancar, sebagai peneduh, produsen oksigen dan penyerap air hujan serta penyedia habitat satwa dan penyerap poluten media udara.

\section{PENUTUP}

Ruang Terbuka Hijau di Provinsi Kalimantan Barat mengacu pada peraturan paling tinggi yaitu UU Penataan Ruang dimana Ruang terbuka hijau adalah area memanjang/jalur dan/atau mengelompok, yang penggunaannya lebih bersifat terbuka, tempat tumbuh tanaman, baik yang tumbuh secara alamiah maupun yang sengaja ditanam.

Pengaturan pembangunan Ruang Terbuka Hijau di Provinsi Kalimantan Barat mengacu pada Undang-Undang Nomor 26 Tahun 2007 tentang Penataan Ruang dan Peraturan Menteri Pekerjaan Umum No. 05/PRT/M/2008 Tentang Pedoman Penyediaan dan Pemanfaatan Ruang Terbuka Hijau di Kawasan Perkotaan.

Upaya Pemerintah Dalam Pembangunan RTH di Provinsi Kalimantan Barat. Pesatnya perkembangan dan pembangunan daerah perkotaan menyebabkan semakin sempitnya lahan terbuka hijau. Oleh karena itu, pemerintah harus membuat peraturan beberapa persen dari bangunan harus ada lahan terbuka hijau. Guna mengantisipasi terjadinya global warming semakin parah, Pemerintah Kabupaten Kubu Raya akan membuat Ruang Terbuka Hijau (RTH) di setiap desa. Kebijakan itu sesuai dengan peraturan dan visi dan misi bupati dalam pemanfaatan 30 persen dari luas desa.

Ruang Terbuka Hijau di seluruh Desa di Kubu Raya agar kedepannya bisa mengantisipasi terjadinya global warming yang semakin parah, langkah ini perlu andil dari semua pihak, satu dintaranya peran pemerintah memberdayakan lahan di setiap desa.

Hal ini penting ditekankan, karena Ruang Terbuka Hujau (RTH) memiliki banyak fungsi, diantaranya untuk memberi jaminan sistem sirkulasi udara dan paru-paru kota, mengatur sistem mikro agar sistem sirkulasi udara dan air secara alami dapat berlangsung lancar, sebagai peneduh, produsen oksigen dan penyerap air hujan serta penyedia habitat satwa dan penyerap poluten media udara. 


\section{DAFTAR PUSTAKA}

\section{BUKU-BUKU}

Boedi Harsono, Hukum Agraria Indonesia Jilid 1 Hukum Tanah Nasional, Penerbit Universitas Trisakti Jakarta 2014.

Bushar Muhammad, Asas-asas Hukum Adat: Suatu Pengantar, cet.6 Jakarta : Pradnya Paramita, 1986.

B. Milles dan A. Michael Haberman, Analisis Data Kualitatif. Terj. Tjetjep Rohendi Rohidi Jakarta, 1992

Hasni, Hukum Penataan Ruang dan Penatagunaan Tanah, (Edisi ke 2), PT. Raja Grafindo Persada Jakarta 2010.

Maria S.W Sumardjono, Puspita Serangkum Masalah Hukum Agraria, Yogyakarta : Liberty, 1982

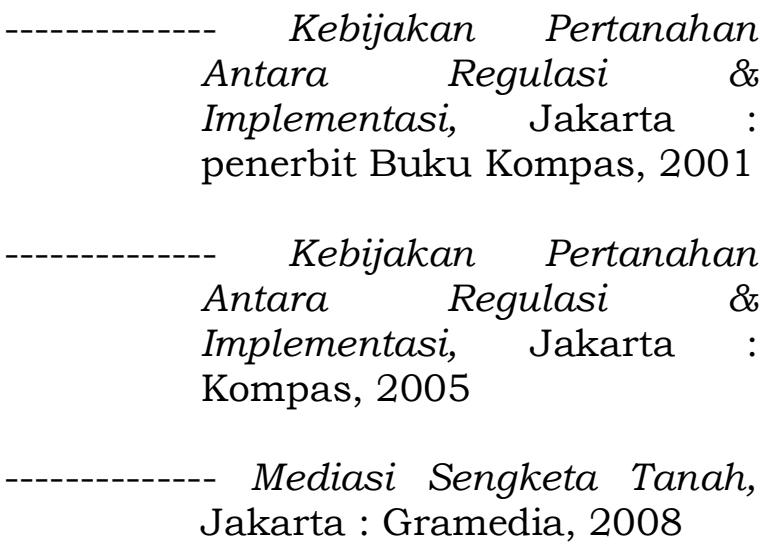

Prof. Ir. Eko Budiharjo, M.Sc dan Ir. Sudanti Harjohubojo, MS Kota Berwawasan Lingkungan, Tanpa Penerbit

Ridwan, HR, Hukum Administrasi Negara, Yogyakarta, UII-Press, 2003.

Sumber : Ditjen Penataan Ruang Dep. Pekerjaan Umum "Ruang Terbuka Hijau Sebagai Unsur Utama Tata Ruang Kota, 2006.

\section{UNDANG-UNDANG}

Undang-Undang No. 32 Tahun 2009 tentang Perlindungan dan Pengelolaan Lingkungan Hidup

Undang-Undang No. 26 Tahun 2007 tentang Penataan Ruang

Undang-Undang No. 5 Tahun 1960 tentang Peraturan Dasar Pokok-pokok Agraria.

Peraturan Pemerintah Nomor 26 Tahun 2008 tentang Rencana Tata Ruang Wilayah Nasional

\section{MAKALAH}

Boedi Harsono, "Menyempumakan HakIIak Atas Tanah Dalam Hukum Tanah Nasional Memasuki Era Reformasi dan Globalisasi", Seminar Nasional, Bagian Hukum Administrasi Negara \& Pusat Studi Hukum Agraria Fakultas Hukum, Universitas Trisakti, Jakarta, 10 Juli 2001 
Boedi Harsono, "Kelemahan Pendaftaran Tanah dengan Sistem Publikasi Negatif', Makalah Seminar Nasional Keefeklifan Lembaga Rechtsverwerking Mengatasi Kelemahan Pendaftaran Tanah Dengan Sistem Publikasi Negatif, Diselenggarakan Oleh Pusat Studi Hukum Agraria Fakultas Hukum Universitas Trisakti. 20 Maret 2002 